\title{
Prolactin and Upstream Migration of the Amphidromous Teleost, Ayu Plecoglossus altivelis
}

\author{
Takashi Yada $^{1 * \#}$, Kei'ichiro Iguchi ${ }^{2 \dagger \#, ~ S h o i c h i r o ~ Y a m a m o t o ', ~ H i r o y u k i ~ S a k a n o ~}{ }^{2 \ddagger}$, \\ Toshihide Takasawa ${ }^{3}$, Kazuhiko Katsura ${ }^{4}$, Nobuhiko Abe ${ }^{4}$, \\ Satoshi Aawata ${ }^{2 \S}$, and Kazuo Uchida ${ }^{1}$
}

\author{
${ }^{1}$ Nikko Station, National Research Institute of Aquaculture, Tochigi 321-1661, Japan \\ ${ }^{2}$ Ueda Station, National Research Institute of Aquaculture, Nagano 386-0031, Japan \\ ${ }^{3}$ Yamagata Prefecture Fisheries Experiment Station, Yamagata 997-1204, Japan \\ ${ }^{4}$ Yamagata Prefecture Inland Fisheries Experiment Station, Yamagata 992-0063, Japan
}

\begin{abstract}
Changes in mRNA levels of prolactin (PRL) during the upstream migration were examined in fry of the amphidromous fish, ayu Plecoglossus altivelis. Quantification of mRNA has been done with real-time PCR and expressed as whole body or pituitary contents depending the body size of fry. PRL mRNA levels of ayu caught in seawater of the coastal area remained low during early spring. Prior to the start of the upstream migration, the fish caught in the coastal area in mid spring showed increased levels of PRL mRNA. There were further increases in PRL levels in the fish caught in the river. Analysis of proportions revealed that there were significant differences among PRL mRNA in the fish caught in different environmental salinities. Body weight showed a positive relation with PRL mRNA in ayu caught in seawater. A landlocked population of ayu, which migrates from lake to river, showed no significant change in PRL mRNA levels before and after upstream migration. Results in this study indicate the importance of up-regulation of PRL gene expression of ayu during the upstream migration from seawater to fresh water. There is a possible relationship between body size and PRL in the early developmental stage of ayu in seawater, but not in the fish in fresh water.
\end{abstract}

Key words: prolactin, osmoregulation, migration, fish, ayu Plecoglossus altivelis

\section{INTRODUCTION}

Prolactin (PRL) is a versatile hormone, which has been implicated in regulating a wide variety of functions, such as reproduction, growth, immunity, behavior, and osmoregulation (Drago, 1984; Hirano, 1986; Bentley, 1998; Bole-Feysot et al., 1998; Schradin and Anzenberger, 1999; Manzon, 2002; Yada and Nakanishi, 2002; Goffin et al., 2002; Angelier and Chastel, 2009). Importance of PRL in migratory behavior is well known in birds in relation to sexual maturation (Meier et al., 1965; Farner and Wingfield, 1980; Bentley, 1998; Holberton et al., 2008). Also in terrestrial amphibians, PRL plays an important role to stimulate "water drive" for spawning (Gona et al., 1973; Ishii et al., 1989; Rankin, 1991). In

\footnotetext{
* Corresponding author. Tel. : : +81-288-55-0055;

Fax : +81-288-55-0064;

E-mail: yadat@fra.affrc.go.jp

\# These authors contributed equally to this work.

Present addreses:

${ }^{\dagger}$ Faculty of Environmental Studies, Nagasaki University, Nagasaki, Nagasaki 852-8521, Japan

$\ddagger$ Fisheries Agency, Ministry of Agriculture, Forestry and Fisheries, Kasumigaseki 100-8950, Japan

$\S$ Sado Marine Biological Station, Niigata University, Sado, Niigata 952-2135, Japan

doi:10.2108/zs130181
}

fish, an increase in PRL gene expression has been found in chum salmon (Oncorhynchus keta) during the spawning migration (Makino et al., 2007; Onuma et al., 2010). However, few studies have examined the separate effect of prolactin on reproduction and migratory behavior using juvenile fish.

It is generally accepted that PRL is a hormone that promotes acclimation to fresh water (FW) in a large number of fish species, and an activation of PRL secretion has been observed in various studies after entry from seawater (SW) to FW (Hirano, 1986; McCormick, 2001; Manzon, 2002; Sakamoto and McCormick, 2006; Lee et al., 2006; Flores et al., 2012). In contrast, decreased secretion of PRL was found in SW-acclimated fish and after experimental transfer from FW to SW, since the sodium-retaining action of $P R L$ is thought to be inhibitory for adaptation to hypertonic environments (Hirano, 1986; Hasegawa et al., 1986; Yada and Hirano, 1992; Yada et al., 1992; McCormick, 2001; Manzon, 2002; Sakamoto and McCormick, 2006). Although the importance of PRL on FW acclimation is well known, it is still unclear whether the increased expression of PRL gene is important for osmoregulation or behavioral regulation during spontaneous entry from SW to FW especially in juvenile stages without sexual maturation.

Some fish species migrate seaward just after hatching to grow in the marine habitat, and then migrate upstream to 

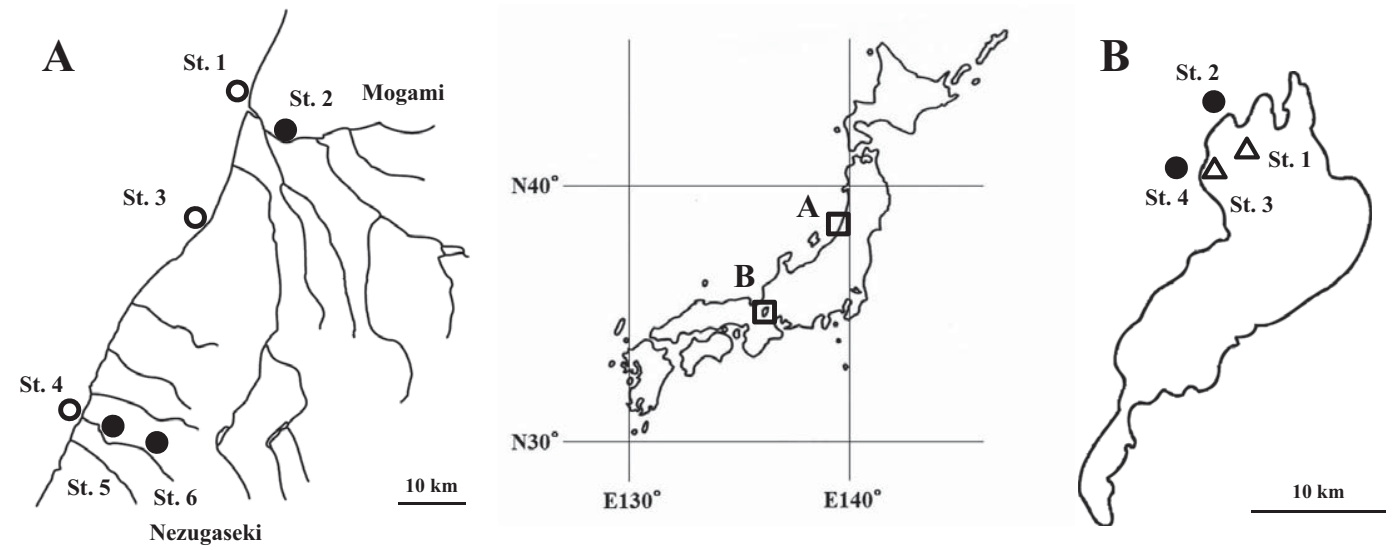

Fig. 1. Maps of the sampling sites in Yamagata (A) and Shiga (B) prefectures of Japan. Coastal $(\bigcirc)$, river $(\bullet)$, and lake $(\triangle)$ sampling sites are shown.

further grow and reproduce in FW; this type of diadromy is categorized as amphidromy (McDowall, 1992). Ayu (Plecoglossus altivelis) is an amphidromous salmonoid fish distributed in East Asia, and is semelparous with an annual life history (Iguchi and Tsukamoto, 2001). Immediately after hatching in autumn, larvae migrate from the bottom of rivers to drift with the current downstream and spend their early life in coastal areas over winter, and then ascend rivers in spring as juveniles (Senta and Kinoshita, 1985; Uchida et al., 1995; Takahashi and Niimi, 1998). Thus, conversion of osmoregulation from uptake to excretion of excess salts in hypertonic environments seems to be important for survival during the early stage of development in SW. Chronologically, immunoreactive-PRL cells appear in the pituitary of ayu one day before hatching (Saga et al., 1999). In a previous study by our group, whole body contents of PRL mRNA in the field samples taken during the downstream migration, in the newly hatched larvae experimentally transferred from FW to SW, and in the developing larvae reared in a vertical salinity gradient showed significant decreases after entry into SW (Yada et al., 2010).

In ayu, a landlocked population which shows migration within FW from lake to river, is available to distinguish between behavioral and osmoregulatory actions of PRL in comparison with the amphidromous population (Nishida, 1986; Takeshima et al., 2009). Ayu thus seems to be an appropriate fish species to examine a possible separate function of $P R L$ in osmoregulation, migratory behavior, and sexual maturation. In contrast to PRL, growth hormone $(\mathrm{GH})$ is known to stimulate osmoregulatory adaptation from $\mathrm{FW}$ to in Yamagata.
Table 1. Position, year, date, water temperature and salinity of sampling sites, and fish body weight

\begin{tabular}{|c|c|c|c|c|c|c|c|}
\hline \multirow[t]{2}{*}{ Site name } & \multicolumn{2}{|c|}{$\begin{array}{l}\text { Latitude and } \\
\text { longitude }\end{array}$} & \multirow[t]{2}{*}{ Year } & \multirow[t]{2}{*}{ Date } & \multirow{2}{*}{$\begin{array}{c}\text { Temperature } \\
\left({ }^{\circ} \mathrm{C}\right)\end{array}$} & \multirow{2}{*}{$\begin{array}{l}\text { Salinity } \\
\text { (ppt) }\end{array}$} & \multirow{2}{*}{$\begin{array}{c}\text { Body weight } \\
\text { (g) }\end{array}$} \\
\hline & ${ }^{\circ} \mathrm{N}$ & ${ }^{\circ} \mathrm{E}$ & & & & & \\
\hline \multirow[t]{9}{*}{ Site 1. Sakata North Bay } & 39.0 & 139.8 & 2006 & March 23 & 9 & 28 & $0.17 \pm 0.10$ \\
\hline & & & & April 27 & 13 & 28 & $0.71 \pm 0.13$ \\
\hline & & & & May 30 & 16 & 27 & $2.37 \pm 0.37$ \\
\hline & & & 2007 & March 23 & 12 & 28 & $0.46 \pm 0.02$ \\
\hline & & & & April 6 & 12 & 27 & $0.78 \pm 0.12$ \\
\hline & & & & April 13 & 13 & 23 & $3.03 \pm 0.39$ \\
\hline & & & & April 26 & 13 & 28 & $4.88 \pm 0.62$ \\
\hline & & & & May 10 & 16 & 27 & $2.06 \pm 0.51$ \\
\hline & & & & May 31 & 19 & 30 & $2.66 \pm 0.30$ \\
\hline Site 2. Mogami River & 38.9 & 139.9 & 2007 & May 10 & 14 & 0 & $1.76 \pm 0.31$ \\
\hline \multirow[t]{2}{*}{ Site 3. Kamo Bay } & 38.8 & 139.7 & 2006 & April 26 & 11 & 30 & $0.92 \pm 0.11$ \\
\hline & & & & May 30 & 18 & 30 & $2.97 \pm 0.26$ \\
\hline Site 4. Nezugaseki Gulf & 38.6 & 139.5 & 2007 & May 10 & 16 & 24 & $0.96 \pm 0.17$ \\
\hline \multirow[t]{2}{*}{ Site 5. Nezugaseki River, lower } & 38.5 & 139.5 & 2006 & May 30 & 13 & 0 & $3.90 \pm 0.33$ \\
\hline & & & 2007 & May 10 & 15 & 0 & $4.45 \pm 0.37$ \\
\hline \multirow[t]{2}{*}{ Site 6. Nezugaseki River, upper } & 38.5 & 139.6 & 2006 & May 30 & 18 & 0 & $4.38 \pm 0.23$ \\
\hline & & & 2007 & May 10 & 11 & 0 & $4.64 \pm 0.65$ \\
\hline
\end{tabular}

SW in several euryhaline fishes, irrespective with its structural similarity to PRL (Madsen and Bern, 1992; McCormick, 2001; Reinecke et al., 2005; Sakamoto and McCormick, 2006; Deane and Woo, 2009). In comparison with PRL, changes in mRNA levels of $\mathrm{GH}$ in ayu was also examined in this study.

\section{MATERIALS AND METHODS}

\section{Animals}

Wild ayu (Plecoglossus altivelis) were collected using a dip net or a casting net in coastal areas and rivers in Yamagata and Shiga prefectures (Fig. 1) and immediately immersed in RNA Later (Ambion, TX). Water temperature, body weight, and/or environmental salinity are shown in Tables 1 and 2 . In some fish, the gonads were dissected and weighted; the gonadosomatic index (GSI, gonadal weight $\times 100 /$ body weight) were less than $0.7 \%$ in all cases and identified as immature (Hirose et al., 1985). Samples were stored at $-20^{\circ} \mathrm{C}$ until RNA extraction. 
Table 2. Position, year, date, and water temperature of sampling sites, and fish body weight in Shiga.

\begin{tabular}{|c|c|c|c|c|c|c|c|}
\hline & \multirow{2}{*}{ Site name } & \multicolumn{2}{|c|}{$\begin{array}{l}\text { Latitude and } \\
\text { longitude }\end{array}$} & \multirow{2}{*}{ Year } & \multirow{2}{*}{ Date } & \multirow{2}{*}{$\begin{array}{c}\text { Temperature } \\
\left({ }^{\circ} \mathrm{C}\right)\end{array}$} & \multirow{2}{*}{$\begin{array}{c}\text { Body } \\
\text { weight }(\mathrm{g})\end{array}$} \\
\hline & & ${ }^{\circ} \mathrm{N}$ & ${ }^{\circ} \mathrm{E}$ & & & & \\
\hline Site 1 & Momose Lake shore & 35.4 & 136.1 & 2007 & May 8 & 17 & $14.0 \pm 1.1$ \\
\hline Site 2 & Shiotsu-Ohkawa River & 35.5 & 136.2 & 2007 & May 8 & 19 & $7.2 \pm 0.6$ \\
\hline Site 3 & Imazugawa Lakeshore & 35.4 & 136.0 & 2010 & June 4 & 22 & $9.8 \pm 1.3$ \\
\hline Site 4 & Imazugawa River & 35.4 & 136.0 & 2010 & June 4 & 22 & $12.9 \pm 0.9$ \\
\hline
\end{tabular}

Body weight is indicated as mean $\pm \mathrm{SE}$.
Yamagata 2006

Site 1

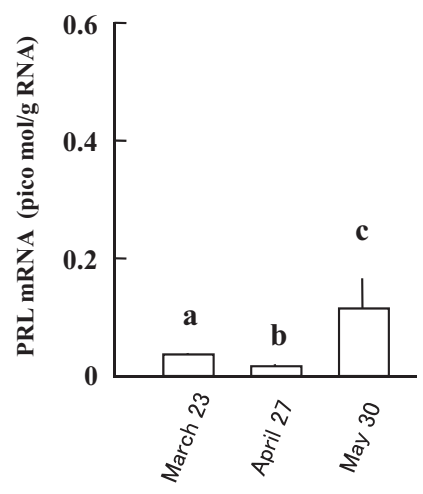

Yamagata 2007

Sites 1 and 2

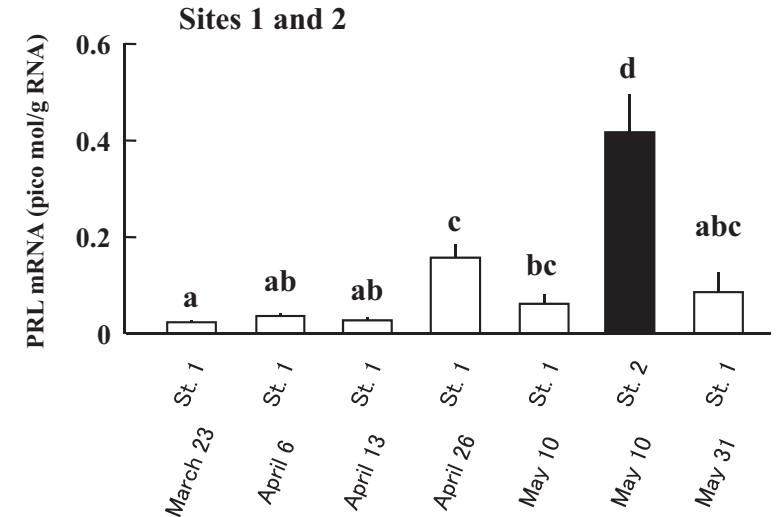

Site 3
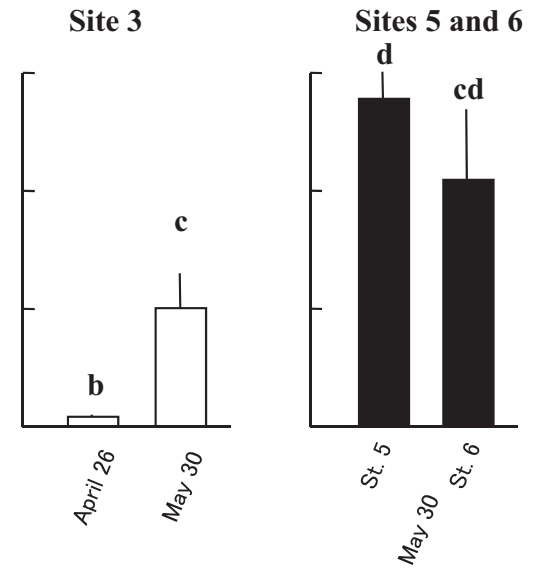

Sites 4-6

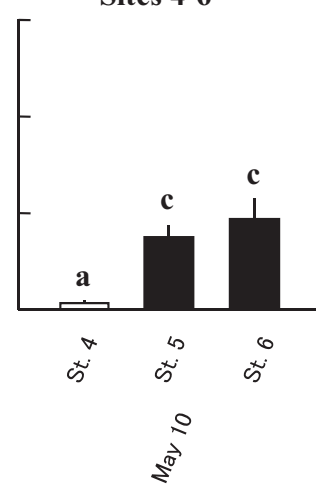

Fig. 2. Whole body contents of PRL mRNA in ayu caught in the coastal area (open column) and river (closed column) in Yamagata in 2006 and 2007. Data are expressed as means + SEM $(n=3-10)$. Different characters represent significance of difference at $P<$ 0.05 .

\section{RNA extraction}

Total RNA was extracted from each fry of ayu from $0.1 \mathrm{~g}$ body weight. When the fish were weighed more than about $1 \mathrm{~g}$, RNA was prepared also in each pituitary isolated after storage in RNA Later. Whole ayu obtained from Yamagata in 2006 and 2007. They were minced using a razor blade, homogenized with a polytron homogenizer (Kinematica, Luzern) in ISOGEN (Nippon Gene, Tokyo), and total RNA was isolated following the manufacturer's manual. Pituitaries dissected from other ayu from Yamagata in 2007 and from Shiga in 2007 and 2010 were also applied for RNA extraction. Total RNA was treated with RNase-free DNase I (Takara, Shiga, Japan). After inactivation of DNase, reverse transcription was carried out using SuperScript II First-Strand Synthesis System (Invitrogen, CA).

\section{Quantitative real-time PCR}

Contents of PRL and GH mRNA of individual fish were estimated by real-time PCR (ABI Prism 7900HT) with TaqMan probes (Applied Biosystems) as described, previously (Yada et al., 2010). The partial cDNA of ayu PRL and $\mathrm{GH}$, cloned and sequenced as described above, was used as the standard. The PCR mixture $(10 \mu \mathrm{L})$ contained $1 \mathrm{x}$ TaqMan Universal PCR Master Mix (Applied Biosystems), $300 \mathrm{nM}$ each of forward and reverse primers, $100 \mathrm{nM}$ of fluorogenic probe, and either standard $\left(6 \times 10^{2}-6 \times\right.$ $10^{7}$ copies/reaction) or product of reverse-transcribed RNA sample (2 ng/reaction). After denaturation at $95^{\circ} \mathrm{C}$ for $10 \mathrm{~min}$, amplification was carried out by 40 cycles of $95^{\circ} \mathrm{C}$ for $15 \mathrm{sec}$ and $60^{\circ} \mathrm{C}$ for $1 \mathrm{~min}$.

\section{Statistical analysis}

After one way analysis of variance (ANOVA), significance of difference between two groups caught on different date or place was analyzed by Student's $t$-test for parametric or Mann-Whitney U-test for non-parametric groups. Analysis of proportions between mRNA level and external salinity was been done using the Kruskal-Wallis test. Spearman's rank correlation coefficient has been applied for analysis between mRNA level and fish body weight. Calculations were performed using a computer program, STATISTICA (Statsoft, OK).

\section{RESULTS}

Figure 2 shows the whole body contents of PRL mRNA in juvenile ayu captured in the coastal areas and rivers of Yamagata in 2006 and 2007. In 2006, ayu caught on 30 May in the coastal areas showed higher levels of PRL mRNA than before in both sites 1 and 3 . On 30 May, fish caught in site 5 located about $500 \mathrm{~m}$ upward from the mouth of Nezugaseki River showed 3- to 4-times higher levels of PRL mRNA than levels of the fish in sites 1 and 3 . Site 6 located $2 \mathrm{~km}$ upward from the river mouth also showed higher levels of PRL mRNA than the coastal areas before 30 May. However, there was no significant difference in PRL mRNA levels between the fish caught in site 6 and in the coastal areas on 30 May.

Whole body contents of PRL mRNA in ayu caught in the coast and river of Yamagata in 2007 showed essentially similar patterns to those in 2006. Samplings at site 1 in every two weeks indicated that PRL mRNA level on April 26 was significantly higher than before. That high level of PRL in the coast was transient and gradually decreased in May. Ayu caught in site 2 located about $1 \mathrm{~km}$ upward from the mouth of Mogami River showed higher PRL levels than all fish caught in site 1, significantly. Sites 5 and 6 in Nezugaseki River also showed higher levels of PRL mRNA than site 4 located in the mouth of same river. On the other hand, there was no significant difference in GH mRNA levels between sampling periods or sites in both 2006 and 2007 (Fig. 3). 

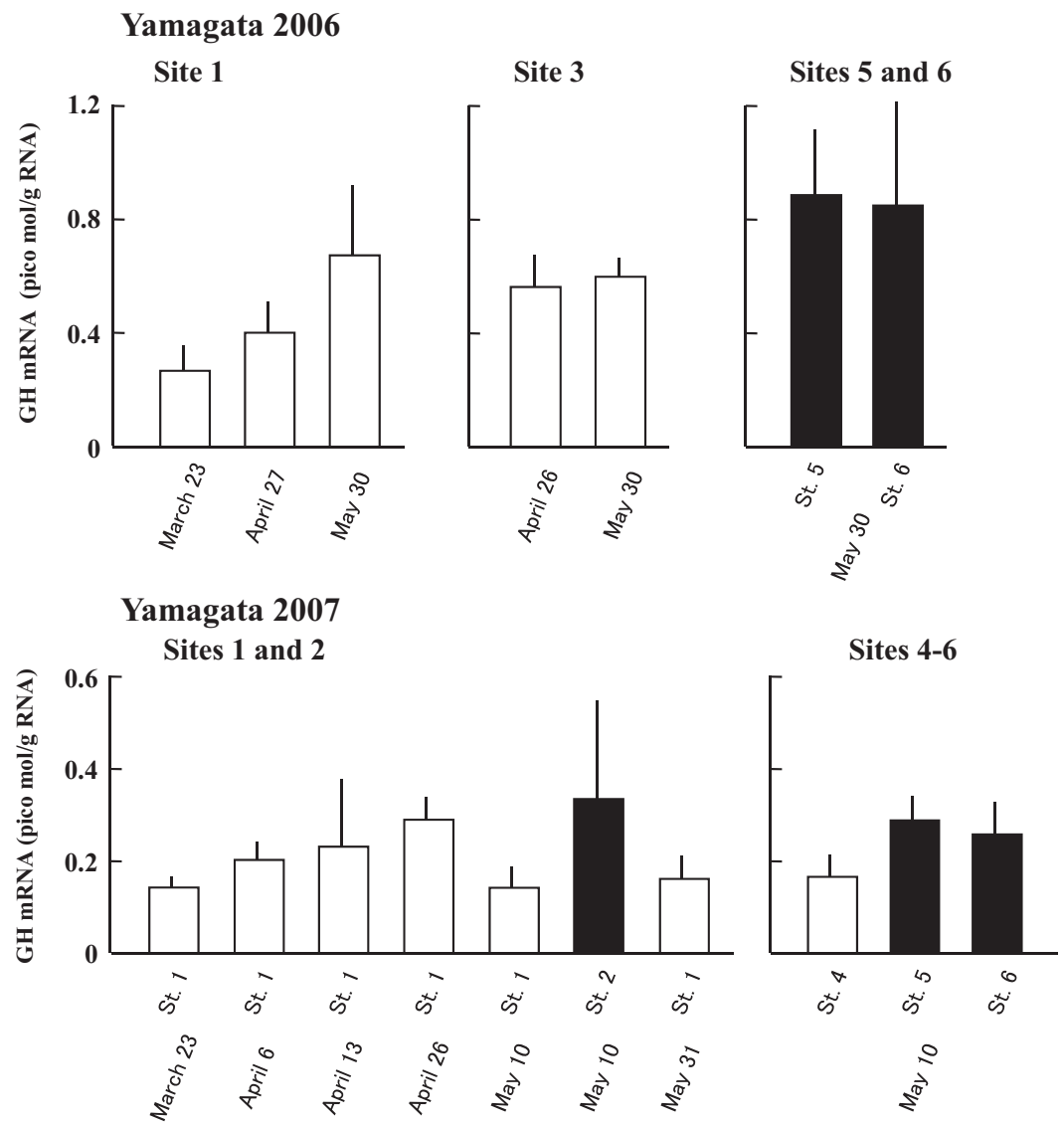

Fig. 3. Whole body contents of GH mRNA in ayu caught in the coastal area (open column) and river (closed column) in Yamagata in 2006 and 2007. Data are expressed as means + SEM $(n=3-10)$. Different characters represent significance of difference at $P<0.05$.
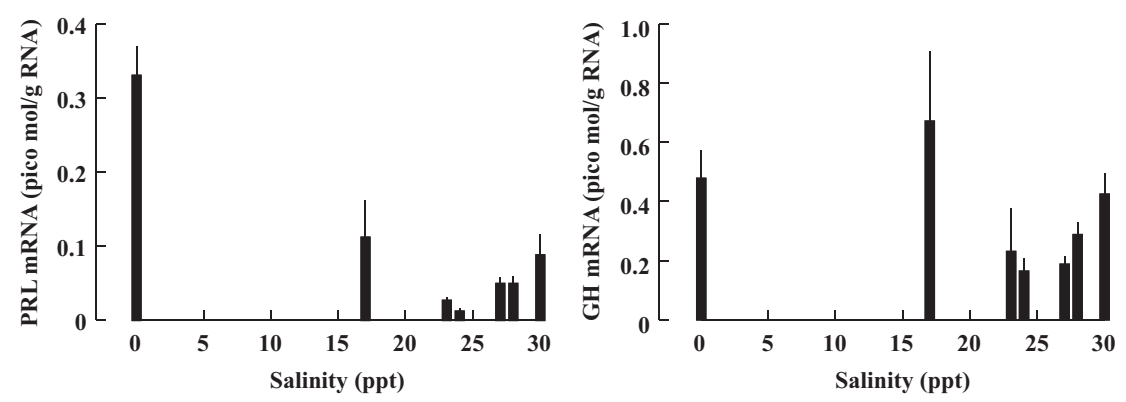

Fig. 4. Relations between salinity and whole body contents of PRL or GH mRNA in ayu caught in the coastal area in Yamagata in 2006 and 2007.
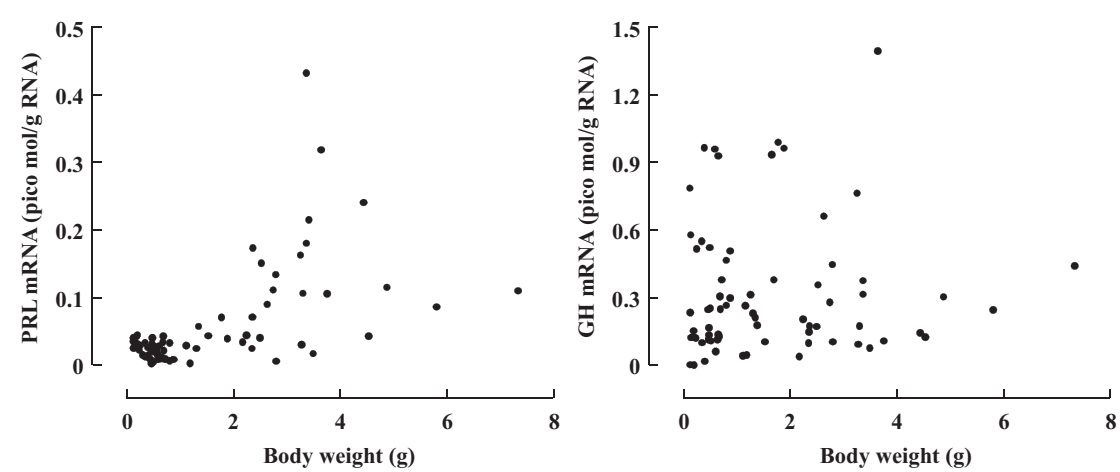

Fig. 5. Relations between body weight and whole body contents of PRL or GH mRNA in ayu caught in the coastal area in Yamagata in 2006 and 2007.
Figure 4 shows relations between environmental salinity of sampling sites and PRL or GH mRNA levels in ayu caught in Yamagata in 2006 and 2007. There were significant differences among PRL mRNA in the fish caught in different environmental salinities (Kruskal-Wallis test, $\left.\chi^{2}=48.34, P<0.01\right)$. There was no significant relation between $\mathrm{GH}$ mRNA and salinity $\left(\chi^{2}=6.11, P>0.05\right)$. On the other hand, a positive correlation was found between body weight and PRL mRNA level in ayu caught in both river and coastal areas (Spearman's rank correlation coefficient, $\left.\mathrm{r}_{\mathrm{s}}=0.66, P<0.05\right)$. In Figure 5, when the fish were limited to the coastal area, there still was a positive relation between the two parameters $\left(r_{s}=\right.$ $0.52, P<0.05)$. There was no significant relation between $\mathrm{GH}$ mRNA and body weight, again $\left(r_{s}=0.10, P>0.05\right)$.

In 2007, PRL mRNA contents in each pituitary were examined in the juvenile ayu caught in the coastal areas and rivers in Yamagata for fish greater than $1 \mathrm{~g}$ in weight (Fig. 6). The values from dissected pituitary standardized with total RNA content were almost $10,000 \times$ higher than those from whole body-homogenate as described above. PRL mRNA on 26 April showed the highest levels among the fish caught in the coastal area in site 1, coinciding well with the changes observed in the whole body levels. Pituitary PRL contents of ayu in site 2 of Mogami River were significantly higher than those in the fish caught in site 1, except for 26 April. Similarly, in Nezugaseki River, an entry from SW in site 4 to FW in sites 5 and 6 resulted in a significant increase in the pituitary contents of PRL mRNA. There was no significant difference in $\mathrm{GH}$ mRNA levels in each pituitary between sampling periods or sites, as the results of whole body contents of mRNA (data not shown). Furthermore, there were significant differences among pituitary contents of PRL mRNA in the fish caught in different environmental salinities as shown among the whole body contents $\left(\chi^{2}=23.25, P<0.01\right)$. There was a positive relation between body weight and pituitary PRL, too (coast and river; $r_{\mathrm{s}}=$ $0.79, P<0.05$, coast only; $r_{\mathrm{s}}=0.84, P<$ $0.05)$.

There was no significant difference in PRL mRNA contents in pituitary of landlocked ayu between the lake and river areas in Shiga in 2007 (Fig. 7). Again in 2010, PRL mRNA contents were compared between the lake and river at 
Yamagata 2007

Sites 1 and 2

Sites 4-6
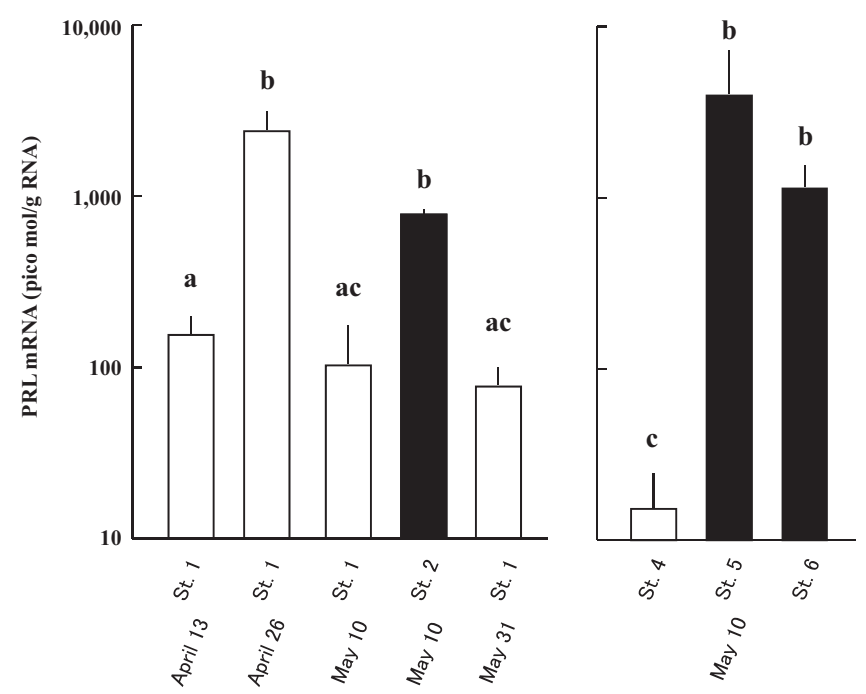

Fig. 6. Pituitary contents of PRL mRNA in ayu caught in the coastal area (open column) and river (closed column) in Yamagata in 2007. Data are expressed as means + SEM $(n=4-6)$. Different characters represent significance of difference at $P<0.05$.

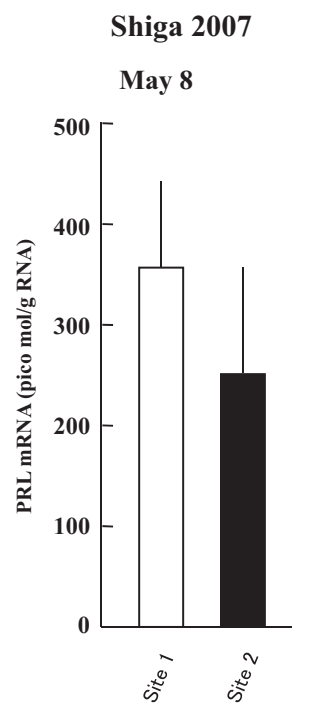

Shiga 2010

$$
\text { June } 4
$$

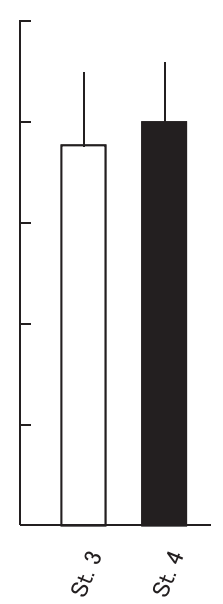

Fig. 7. Pituitary contents of PRL mRNA in ayu caught in the lake (open column) and river (closed column) in Shiga in 2007 and 2010. Data are expressed as means + SEM $(n=6-10)$.

Imazugawa; site 4 located about 100 m upward from site 3. Upward migration from the lake to river produced no significant change in PRL mRNA levels. There was no significant relation between PRL $m R N A$ and body weight $\left(r_{s}=-0.003\right)$.

\section{DISCUSSION}

Results in the present study showed increased levels of $\mathrm{PRL}$ mRNA in wild juvenile ayu after moving from the coastal area to the river. After forced experimental transfer from SW to FW, elevations of PRL production and release, which were deduced from increased plasma levels and pitu- itary mRNA contents, have been reported in a large number of fish species (Hirano, 1986; McCormick, 2001; Manzon, 2002; Sakamoto and McCormick, 2006; Lee et al., 2006). On the other hand, few studies have examined the roles of PRL during spontaneous entry of wild fish from SW to FW in the field. Increased levels of circulating $P R L$ and $P R L$ receptor mRNA in gills are observed in maturing wild sockeye salmon (O. nerka) during upstream migration (Flores et al., 2012). The spontaneous entry from the coastal area to the river is generally known in homing salmon, and their migratory behavior is thought to be closely linked to reproductive processes. In maturing chum salmon, influences of FW entry on plasma levels or pituitary mRNA contents of $P R L$ are equivocal, some indicating an increase, and other reporting a decrease or no change (Hirano et al., 1985; Onuma et al., 2010). These contradictory results could be due to complex relationships between osmoregulation, behavior, and reproduction, or PRL and other sex steroids (Makino et al., 2007). Ayu is known to spawn normally from September to October, and plasma levels of sex steroids of immature ayu were much lower than the matured one (Hirose et al., 1985). The fish used in the present study from March to June were identified as immature based on their reproductive stages by the low GSI value (Yoshida et al., 2001). Juvenile ayu captured in the river showed higher whole body contents of PRL mRNA than those caught in the coastal area. In the pituitary contents, PRL mRNA levels in FW were significantly higher than those in SW. Furthermore, pituitary contents of PRL mRNA in the amphidromous ayu, which entered from SW into FW, were 4-10 times higher than those of the landlocked ayu dwelling only in FW. In wild juvenile ayu spontaneously selecting environmental salinity, higher PRL mRNA levels responding to lower salinity support the importance of up-regulation of PRL gene expression during upstream migration of amphidromous fish.

Migratory behavior of birds and amphibians is known to be driven by $P R L$ in relation to reproduction (Meier et al., 1965; Gona et al., 1973; Ishii et al., 1989; Rankin, 1991; Bentley, 1998; Bole-Feysot et al., 1998; Holberton et al., 2008). Also in teleost species, $P R L$ is thought to be an important regulator of behavior, especially in nesting and parental care (Ball, 1969; De Vlaming, 1979; Bentley 1998; Schradin and Anzenberger, 1999). In landlocked ayu, there was no significant difference in PRL levels between the before and after upstream migration from $\mathrm{FW}$ to $\mathrm{FW}$. That negative result suggests that $P R L$ is less important for migratory behavior or selection of habitat than adaptation for different salinities in this salmonoid fish species. In other words, PRL is necessary for the migration accompanying a change in environmental salinity.

The fish caught in the bay areas on 30 May, 2006, and 26 April, 2007, represented significantly higher whole body contents of PRL mRNA than before in the same sites. In 2007, serial samplings revealed that the high PRL mRNA was followed by a return to the low initial levels. That single elevation of PRL mRNA was more obvious when quantification has been done in each pituitary, suggesting an increased production of PRL prior to the entry to low salinity. In comparison of data from several years in Ishikari Bay in Japan, Makino et al. (2007) suggested that the amounts of PRL mRNA in homing chum salmon in SW were already 
elevated before the entry to FW. The high level of PRL mRNA was also observed in maturing chum salmon caught in the Bering Sea in comparison with those in the Gulf of Alaska (Makino et al., 2007). Elevation of PRL mRNA levels in SW-dwelling fish seems to be paradoxical owing to the inhibitory action of $P R L$ for adaptation to hypertonic environment (Hirano, 1986; McCormick, 2001; Manzon, 2002; Sakamoto and McCormick, 2006). On the other hand, with an opposite direction of salinity change to the present study, PRL mRNA content significantly decreased prior to a movement of larval ayu from FW to SW in a tank with vertical salinity layers (Yada et al., 2010). In the fish spontaneously migrating and selecting salinity, $P R L$ production may change before the timing of entry to different salinities.

In contrast to the negative relation with salinity, PRL mRNA levels showed a significant positive relation to body weight in ayu caught in Yamagata. Even when the ayu was limited to the fish caught in SW, there still was a positive relation between body weight and PRL. Furthermore, that positive relation was also found for specific dates, 30 May in 2006 and 10 May in 2007 (data not shown). On the other hand, there was no significant relation between body weight and PRL levels in landlocked ayu in Shiga. These different results between the SW-dwelling and landlocked ayu suggest that the relation between body size and PRL was closely related to the environmental salinity. Larger ayu shows a tendency to migrate upstream from the coast to the river sooner than smaller fish (Tago, 2004). Similar to ayu, body size is known to relate to the timing of downstream migration in juvenile salmons; larger fish move sooner and acclimate easier to different salinities than smaller fish (Parry, 1958; Ewing et al., 1984; Bjerknes et al., 1992; Beckman et al., 1998). Water temperature is known to be an important environmental factor affecting the upstream migration of ayu in relation to the body size (Tago, 2004). However, in our previous study, there is no influence of water temperature on PRL mRNA levels in ayu larvae (Yada et al., 2010). Although there are significant interrelationships among body size, temperature, and upstream migration of ayu, the possible role of PRL in this process seems to be limited in the osmoregulatory adaptation.

As discussed above, PRL gene expression seems to be activated not only after, but also before the entry to FW in ayu. Larger ayu in SW may express PRL gene more than the smaller fish to prepare the upcoming moving to FW. A positive relation between body size and PRL MRNA levels in SW-dwelling ayu may be associated with a growthpromoting effect of PRL, which has been observed repeatedly among a wide variety to vertebrates (Ball, 1969; De Vlaming, 1979; Hirano, 1986; Bole-Feysot et al., 1998; Goffin et al., 2002). However, there is no significant relation between body size and PRL in landlocked ayu. We thus conclude that a positive relation between body size and PRL observed in ayu derives mainly from the osmoregulatory role of PRL but not from its growth-promoting action.

The variation of body size for the animals used in this study was large especially in SW-dwelling fish in Yamagata. Ayu is an annual fish and there must not be multiple year classes (Tsukamoto and Uchida, 1992). Then, one of the possible reason of variation of fish body size is the width of birth dates within a year. Ayu is known as a multiple spawn- ing fish and the spawning period is varied for several months in autumn (Shimizu et al., 2005). And another important factor seems to be growth rate during ocean, which is varied by the opportunity to catch the food (Tsukamoto and Uchida, 1992).

One of the most important growth-promoting hormones, $\mathrm{GH}$ showed no significant difference in mRNA levels between sampling sites, periods, environmental salinities, or body sizes in this study. That lack of difference in $\mathrm{GH}$ coincided with our previous study with ayu larvae (Yada et al., 2010). In contrast to PRL, GH promotes acclimation from FW to SW in several euryhaline fishes (Madsen and Bern, 1992; McCormick, 2001; Reinecke et al., 2005; Sakamoto and McCormick, 2006; Deane and Woo, 2009). Increases in plasma levels and gene expression of $\mathrm{GH}$ have been observed repeatedly after entry from FW to SW (Yada et al., 1992, 1994; Sakamoto et al., 1993; Sakamoto and McCormick, 2006; Deane and Woo, 2009; McCormick et al., 2013). On the other hand, there was a significant decline in plasma levels of $\mathrm{GH}$ after SW entry of Atlantic salmon (Salmo salar), suggesting complicated changes in the kinetics of production, release, and clearance of GH (Arnesen et al., 2003). GH mRNA quantified in the present study may reflect gene transcription, but may not be a direct indicator of secretion, clearance, or reception of $\mathrm{GH}$ bringing about physiological functions, such as growth and SW acclimation.

Ayu during spontaneous upstream migration from SW to FW represents a necessity of PRL for adaptation to novel hypoosmotic environments. Comparisons between SWdwelling ayu in Yamagata and landlocked ayu in Shiga imply that PRL have more important implications for osmoregulation than for behavior, growth, or reproduction in this salmonoid fish. In addition to PRL, several endocrine factors are thought to play important roles in the regulation of fish migration, such as thyroid hormone, gonadotropin-releasing hormone, corticotrophin-releasing hormone, $\mathrm{GH}$, and insulin-like growth factor-I (Rankin, 1991; Iwata, 1995; Ueda and Yamauchi, 1995; Clements, 2002; Makino et al., 2007; Onuma et al., 2010; McCormick et al., 2013). The results of this study also indicate the importance of endocrine regulation during migration of amphidromous fish, and further studies are needed in a view of success of migration as survival and growth in the river.

\section{ACKNOWLEDGMENTS}

We are grateful to Professor Susumu Hyodo, Atmosphere and Ocean Research Institute, University of Tokyo, Dr. Stephen D. McCormick, Conte Anadromous Fish Research Center, United States Geological Survey, and Dr. Yasuhiko Tago, Toyama Prefectural Fisheries Research Institute, for valuable discussions and encouragements during the study. This study was supported in part by a grant-in-aid from Agriculture, Forestry and Fisheries Research Council, Japan.

\section{REFERENCES}

Arnesen AM, Toften H, Agustsson T, Stefansson SE, Handeland SO, Björnsson BT (2003) Osmoregulation, feed intake, growth and growth hormone levels in 0+ Atlantic salmon (Salmo salar L.) transferred to seawater at different stages of smolt development. Aquaculture 222: 167-187

Angelier F, Chastel $O$ (2009) Stress, prolactin and parental investment in birds: a review. Gen Comp Endocirnol 163: 142-148 
Ball JN (1969) Prolactin (fish prolactin or paralactin) and growth hormone. In "Fish Physiology, Vol 2" Ed by WS Hoar, DJ Randall, Academic Press, London, pp 207-240

Beckman BR, Larsen DA, Lee-Pawlak B, Dichoff WW (1998) Relation of fish size and growth rate to migration of spring chinook salmon smolts. North Am J Fish Manage 18: 537-546

Bentley PJ (1998) Comparative Vertebrate Endocrinology. 3rd ed. Cambridge University Press, Cambridge

Bjerknes V, Duston J, Knox D, Harmon P (1992) Importance of body size for acclimation of underyearing Atlantic salmon parr (Salmo salar L.) to seawater. Aquaculture 104: 357-366

Bole-Feysot C, Goffin V, Edery M, Binart N, Kelly PA (1998) Prolactin (PRL) and its receptor: actions, signal transduction pathways and phenotypes observed in PRL receptor knockout mice. Endoc Rev 19: 225-268

Clements S, Schreck CB, Larsen DA, Dickhoff WW (2002) Central administration of corticotrophin-releasing hormone stimulates locomotor activity in juvenile chinook salmon (Oncorhynchus tshawytscha). Gen Comp Endocrinol 125: 319-327

Deane EE, Woo NYS (2009) Modulation of fish growth hormone levels by salinity, temperature, pollutions and aquaculture related stress: a review. Rev Fish Biol Fish 19: 97-120

De Vlaming VL (1979) Actions of prolactin among the vertebrates. In "Hormones and Evolution, Vol 2" Ed by EJW Barrington, Academic Press, New York, pp 561-642

Drago F (1984) Prolactin and sexual behavior: a review. Neurosci Biobehav Rev 8: 433-439

Ewing RD, Hart CE, Fustish CA, Concannon G (1984) Effects of size and time of release on seaward migration of spring chinook salmon, Oncorhynchus tshawytscha. Fish Bull 82: 157-164

Farner DS, Wingfield JC (1980) Reproductive endocrinology of birds. Ann Rev Physiol 42: 457-472

Flores A-M, Shrimpton JM, Patterson DA, Hills JA, Cooke SJ, Yada $T$, et al. (2012) Physiological and molecular endocrine changes in maturing wild sockeye salmon, Oncorhynchus nerka, during ocean and river migration. J Comp Physiol B 182: 77-90

Goffin V, Binart N, Touraine P, Kelly PA (2002) Prolactin: the new biology of an old hormone. Ann Rev Physiol 64: 47-67

Gona AG, Pearlman T, Gona O (1973) Effects of prolactin and thyroxine in hypophysectomized and thyroidectomized red efts of the newt Notophthalmus (Diemictylus) viridescens. Gen Comp Endocrinol 20: 107-111

Hasegawa S, Hirano T, Kawauchi H (1986) Sodium-retaining activity of chum salmon prolactin in some euryhaline teleosts. Gen Comp Endocrinol 63: 309-317

Hirano T (1986) The spectrum of prolactin action in teleosts. In "Comparative Endocrinology: Developments and Directions" Ed by CL Ralph, AR Liss, New York, pp 53-74

Hirano $\mathrm{T}$, Prunet $\mathrm{P}$, Kawauchi $\mathrm{H}$, Takahashi A, Ogasawara $\mathrm{T}$, Kubota J, et al. (1985) Development and validation of a salmon prolactin radioimmunoassay. Gen Comp Endocrinol 59: 266276

Hirose K, Adachi S, Nagahama Y (1985) Changes in plasma steroid hormone levels during sexual maturation in the ayu Plecoglossus altivelis. Bull Jap Soc Sci Fish 51: 399-403

Holberton RL, Boswell T, Hunter MJ (2008) Circulating prolactin and corticosterone concentrations during the development of migratory condition in the dark-eyed junco, Junco hyemalis. Gen Comp Endocrinol 155: 641-649

Iguchi K, Tsukamoto Y (2001) Semelparous or iteroparous: resource allocation tactics in the ayu, an osmeroid fish. J Fish Biol 58: 520-528

Ishii S, Yoneyama H, Inoue M, Yamamoto K, Kikuyama S (1989) Changes in plasma and pituitary levels of prolactin in the toad, Bufo japonicus, throughout the year with special reference to the breeding migration. Gen Comp Endocrinol 74: 365-372

Iwata M (1995) Downstream migratory behavior of salmonids and its relationship with cortisol and thyroid hormones: a review. Aquaculture 135: 131-139

Lee LM, Kaneko T, Katoh F, Aida K (2006) Prolactin gene expression and gill chloride cell activity in fugu Takifugu rubripes exposed to a hypoosmotic environment. Gen Comp Endocrinol 149: 285-293

Madsen SS, Bern HA (1992) Antagonism of prolactin and growth hormone: impact in seawater adaptation in two salmonids, Salmo trutta and Oncorhynchus mykiss. Zool Sci 9: 775-784

Makino K, Onuma TA, Kitahashi T, Ando H, Ban M, Urano A (2007) Expression of hormone genes and osmoregulation in homing chum salmon: a minireview. Gen Comp Endocrinol 152: 304309

Manzon LA (2002) The role of prolactin in fish osmoregulation: a review. Gen Comp Endocrinol 125: 291-310

McCormick SD (2001) Endocrine control of osmoregulation in teleost fish. Amer Zool 41: 781-794

McCormick SD, Sheehan TF, Björnsson BT, Lipsky C, Kocik JF, Regish AM, O'Dea MF (2013) Physiological and endocrine changes in Atlantic salmon smolts during hatchery rearing, downstream migration, and ocean entry. Can J Fish Aquat Sci 70: $105-118$

McDowall RM (1992) Diadromy: origins and definitions of terminology. Copeia 1992: 248-251

Meier AH, Farner DS, King JR (1965) A possible endocrine basis for migratory behavior in the white-crowed sparrow, Zonotrichia leucophrys gambelii. Anim Behav 13: 453-465

Nishida M (1986) Geographic variation in the molecular, morphological and reproductive characters of the ayu Plecoglossus altivelis (Plecoglossidae) in the Japan-Ryukyu archipelago. Jpn J Ichthyol 33: 232-248

Onuma TA, Ban M, Makino K, Katsumata H, Hu WW, Ando H, et al. (2010) Changes in gene expression for GH/PRL/SL family hormones in the pituitaries of homing chum salmon during ocean migration through upstream migration. Gen Comp Endocrinol 166: $537-548$

Parry G (1958) Size and osmoregulation in salmonid fishes. Nature 181: $1218-1219$

Rankin MA (1991) Endocrine effects on migration. Amer Zool 31: 217-230

Reinecke M, Björnsson BT, Dickhoff WW, McCormick SD, Navarro I, Power DM, Gutiérrez J (2005) Growth hormone and insulinlike growth factors in fish: where we are and where to go. Gen Comp Endocrinol 142: 20-24

Saga T, Yamaki K, Doi Y, Yoshizuka M (1999) Chronological study of the appearance of adenohypophysial cells in the ayu (Plecoglossus altivelis). Anat Embryol 200: 469-475

Sakamoto T, McCormick SD (2006) Prolactin and growth hormone in fish osmoregulation. Gen Comp Endocrinol 147: 24-30

Sakamoto T, McCormick SD, Hirano T (1993) Osmoregulatory actions of growth hormone and its mode of action in salmonids: a review. Fish Physiol Biochem 11: 155-164

Schradin C, Anzenberger G (1999) Prolactin, the hormone of paternity. News Physiol Sci 14: 223-231

Senta T, Kinoshita I (1985) Larval and juvenile fishes occurring in surf zones of western Japan. Trans Am Fish Soc 114: 609-618

Shimizu A, Uchida K, Abe S, Udagawa M, Sato T, Katsura K (2005) Evidence of multiple spawning in wild amphidromous type ayu. Fish Sci 71: 1379-1381

Tago Y (2002) Larval distribution of ayu Plecoglossus altivelis in the surface layer of estuary regions in Toyama Bay. Nippon Suisan Gakkaishi 68: 61-71 (in Japanese with English summary)

Takahashi I, Niimi K (1998) Life history of ayu, Plecoglossus altivelis, in the Yahagi river-I spawning of ayu and downstream migration of their larvae. Rep Yahagi Riv Inst 2: 225-245 (in Japanese)

Takeshima H, Iguchi K, Nishida M (2009) Ayu (Plecoglossus altivelis) in a contact zone between amphidromous and landlocked 
forms: genetic analyses of populations in the Yodo river system. Zool Sci 26: 536-542

Tsukamoto K, Uchida K (1992) Migration mechanism of the ayu. In "Oceanic and Anthropogenic Controls of Life in the Pacific Ocean" Ed by VI llyichev, VV Anikiev, Kluwer Academic Publishers, Dordrecht, pp 145-172

Uchida K, Iguchi K, Kiso K (1995) Effects of water temperature on aggressive behavior of the territorial ayu Plecoglossus altivelis in aquaria. Bull Natl Res Inst Fish Sci 7: 389-401

Ueda H, Yamauchi K (1995) Biochemistry of fish migration. In "Biochemistry and Molecular Biology of Fishes, Vol 5" Ed by PW Hochachka, TP Mommsen, Elsevier, Amsterdam, pp 265-279

Yada T, Hirano T (1992) Influence of seawater adaptation on prolactin and growth hormone release from organ-cultured pituitary of rainbow trout. Zool Sci 9: 143-148

Yada T, Nakanishi T (2002) Interactions between endocrine and immune system in fish. Int Rev Cytol 220: 35-92

Yada T, Kobayashi T, Urano A, Hirano T (1992) Changes in growth hormone and prolactin messenger ribonucleic acid levels during seawater adaptation of amago salmon (Oncorhynchus rhodurus). J Exp Zool 262: 420-425

Yada T, Hirano T, Grau EG (1994) Changes in plasma levels of the two prolactins and growth hormone during adaptation to different salinities in the euryhaline tilapia, Oreochromis mossambicus. Gen Comp Endocrinol 93: 214-223

Yada T, Tsuruta T, Sakano H, Yamamoto S, Abe N, Takasawa T, et al. (2010) Changes in prolactin mRNA levels during downstream migration of the amphidromous teleost, ayu Plecoglossus altivelis. Gen Comp Endocrinol 167: 261-267

Yoshida D, Nagae M, Ito F, Soyano K (2001) Molecular cloning of cDNAs encoding pituitary glycoprotein hormone $\alpha, \mathrm{FSH} \beta$ and LH $\beta$ subunits in ayu, Plecoglossus altivelis. Zool Sci 18: 929936

(Received December 10, 2013 / Accepted April 10, 2014) 